\title{
ASSESSMENT OF THE AGRONOMIC PERFORMANCE OF TWO VARIETIES OF SOYBEAN AS INFLUENCE BY TIME OF INTRODUCTION OF MAIZE AND CROPPING PATTERN
}

\author{
Philip O. Osang ${ }^{1}$, Richard I. B. ${ }^{2}$ and M. M. Degri ${ }^{3}$ \\ ${ }^{1}$ Department of Agronomy, Faculty of Agriculture and Forestry, Cross River State University of \\ Technology, Obubra, Nigeria \\ ${ }^{2}$ Department of Crop Protection, Faculty of Agriculture, University of Maiduguri, Nigeria. \\ ${ }^{3}$ Department of Agronomy, Faculty of Agriculture, Federal University,Kashere, Gombe State, Nigeria.
}

Corresponding Author Email address: mikedegri@gmail.com

\begin{abstract}
Field experiments were conducted to assess the effect of time of introduction of maize and cropping pattern on two varieties of soybean in a soybean/maize intercrop in 2007 and 2008 seasons at the University of Agriculture Makurdi. Three periods of introduction of maize were evaluated: (i) planting at the same time with soybean;(ii) introduction of maize two weeks after planting soybean and (iii) introduction of maize four weeks after planting soybean. There were five cropping patterns viz: (i) soybean variety Samsoy-2 planted sole (ii) soybean variety TGX 1448-2E planted sole (iii) maize variety DMR-ESR-Y planted sole (iv) Samsoy -2 intercrop with maize and (v) TGX1448-2E intercrop with maize. The experiment was a split plot laid on complete randomized block design replicated three times. Results obtained revealed that there was no significant effect of time of introduction of maize on any soybean parameter observed. Yield and yield components of soybean indicated significant effect of cropping pattern $(\mathrm{P}<0.01)$ with number of pods per plant and grain yield. Grain yield and number of pods per plant decreased in intercrop with soybean variety Samsoy-2 having the highest number of pods per plant and grain yield. The result on maize indicated that maize planted sole was significantly $(\mathrm{P}<0.01)$ taller than intercropped maize, there was significant $(\mathrm{P}<0.01)$ effect of time of introduction of maize and cropping pattern on maize plant height, ear length, ear diameter, survival and barrenness percentage and grain yield. The Land Equivalent ratio (LER) values indicated that higher yield advantages were obtained from maize introduced two weeks after planting soybean and maize intercropped with soybean variety Samsoy-2 (1.35) than with soybean variety TGX1448-2E (1.12).
\end{abstract}

Keywords: Time of introduction, variety, cropping pattern, yield, Land Equivalent Ratio.

\section{INTRODUCTION}

Southern Guinea Savannah of Nigeria is a major producer of cereals and legumes. The ecological characteristics of the zone have been described by Agboola, (1979) and Agabi, et al.,(1995) as good for production of cereals, legume and some tree crops.

Soybean (Glycine max. L.) is chiefly grown in Benue State as cash crop by small scale farm holders who grow it sole or in mixture simultaneously with cereals. The crop has become an integral component of the traditional cropping systems of this agro ecological zone due to its beneficial effect on sustainability and nutritious food ( Henriet et al., 1997 ). Maize ( Zea mays $L$.) is grown almost in all parts of the country except where rainfall becomes a limiting factor; it is increasingly being accepted as a major source of food and cash income among its predominantly small holder producers in Nigeria (NARP, 1994).

Although the bulk of soybean production takes place in crop mixture, most of the cultivars were developed and tested under the sole cropping condition. Studies on evaluation of genotype for the adaptability to intercropping have indicated differential responses of 
genotype to cropping systems (Biabani et al., 2008; Mudita et al., 2008). Intercropping is the traditional farming system of the tropics, in this system, the component crops in the mixture are not always sown at the same date, and the crops may be sown at the same time or different times depending on the farmer's preferences (Francis, 1978; Remison, 1982; Ofori and Stern, 1987). The performance of a crop in mixture might vary depending on when it is sown relative to the companion crop (Baker, 1978; Zhang and Li, 2003). IITA (1989) recommended proper adjustment of time of sowing and spacing and plant types so as to minimize competition for light to enhance productivity, that the growth habit and plant architecture must be considered when deciding to defer planting of any component crop.

The productivity of legumes in legumes/cereals intercropping is reported to be low (Ennin et $a l ., 2002)$. A number of measures have been recommended for achieving increase in legume productivity in intercropping among which are - Identification of shade tolerant varieties (Francis, 1986), identifying the best suitable time of sowing the component crop in the intercropping (Singh and Ajeigbe, 2002) and choice of suitable companion crop in the intercropping (Olufajo, 1995). Recent reviews emphasize the need for research on how to minimize competition through tolerant varieties for intercropping (Biabani et al.,.2008; Mudita et al.,2008) and time of sowing component crop in the intercropping (Singh and Ajeigbe, 2002; Olufajo and Singh, 2002). The objective of this study was to investigate the performance of two varieties of soybean as influenced by time of introduction of maize and intercropping pattern.

\section{MATERIALS AND METHODS}

Field experiments were conducted during the 2007 and 2008 cropping seasons to investigate the influence of date of planting and time of introduction of maize in a soybean/maize intercropping system at the Teaching and Research farm of the University of Agriculture, Makurdi $\left(7.41^{\circ} \mathrm{N} ; 8.28^{\circ} \mathrm{E}\right)$ which falls within the Southern Guinea Savannah agro-ecological zone of Nigeria.

The experimental design was a $3 \times 5$ split plot laid in a randomized complete block design replicated three times. Three times of introduction of maize (planting soybean and maize simultaneously, maize introduced two weeks after planting soybean and maize introduced four weeks after planting soybean) and five cropping patterns (soybean variety- Samsoy-2 sole, soybean variety- TGX 1448-2E sole, maize variety DMR-ESR-Y planted sole, maize variety intercrop with Samsoy-2, maize intercrop with TGX1448-2E).Maize variety DMRESR-Y and soybean variety TGX1448-2E and Samsoy-2 were obtained from National Cereal Research Institute sub- station Gboko. Each experimental unit (plot size) measured 5mx3m with four ridges of $5 \mathrm{~m}$ long spaced $0.75 \mathrm{~m}$, site clearing and ridge making was done manually, spacing for sole maize was recommended spacing of $0.75 \mathrm{~m}$ x $0.5 \mathrm{~m}$ at 2 plants per stand giving a population of approximately 53,333 plants per hectare. Intercrop maize was spaced $0.75 \mathrm{~m} \times 0.5 \mathrm{~m}$ at one plant per stand using the semi additive mixture as stated by Fisher (1977) giving a population of approximately 26,666 plants per hectare. Spacing for soybean was $0.75 \mathrm{~m} \times 0.05 \mathrm{~m}$ at one plant per stand giving a population of approximately 266,666 plants per hectare. Maize seeds were sown (4 seeds/hill) on the side of the ridges and thinned to two plants per stand for sole and one plant per stand for intercrop, soybean was sown on top of the ridges with the seeds drilled, which were thinned to one plant per stand both for sole and intercrop.

Fertilizer was applied based on recommended fertilizer rates for Benue State as followsmaize sole- $90 \mathrm{kgN} / \mathrm{ha}, 45 \mathrm{kgP}_{2} \mathrm{O}_{5}$ ha and $45 \mathrm{kgK}_{2} \mathrm{O} / \mathrm{ha}(300 \mathrm{~kg}$ of NPK:15:15:15/ha as first split application and $100 \mathrm{~kg}$ urea/ha as second split application).

Soybean -- $10 \mathrm{kgN} / \mathrm{ha}, 36 \mathrm{kgP}_{2} \mathrm{O}_{5} / \mathrm{ha}$ and $20 \mathrm{kgK}_{2} \mathrm{O} / \mathrm{ha}(22 \mathrm{~kg}$ of urea/ha, $200 \mathrm{~kg}$ of $\mathrm{SSP} / \mathrm{ha}$ and $33 \mathrm{~kg} / \mathrm{ha}$ of MOP). 
Intercrop - 200kg/ha of NPK-15:15:15 as first split application and $200 \mathrm{~kg} / \mathrm{ha}$ of SSP on soybean and $100 \mathrm{~kg} / \mathrm{ha}$ of urea on maize as second split application (.Kalu, 1993). Data collected on maize were plant height, number of days to $50 \%$ tasseling and silking, numbers of leaves per plant, leaf area, numbers of ears per plant, ear diameter, ear length, percent survival, percent barrenness, weight of 100 seeds and net yield. Data collected on soybean were - plant height, number of days to $50 \%$ flowering, number of primary branches, number of pods per plant, number of seeds per pod, leaf area, weight of 100 seeds and net yield.

Both crops were harvested when they were fully matured and dried. All the data collected were subjected to analysis of variance using GENSTAT (2003) statistical package. Land Equivalent Ratio was computed as stated by Mead and Willey (1980). Competitive Ratio was computed as stated by Willey and Rao (1980)

\section{RESULTS}

Soybean- The result on soybean showed that time of introduction of maize $(T)$ had no significant effect on any vegetative flowering traits of soybean (Table 1). Leaf area and days to $50 \%$ flowering of soybean were significantly affected by cropping pattern, while no significant effect was observed on soybean plant height and number of branches. Generally, there was an increase in leaf area and days to $50 \%$ flowering for soybean intercropped. There was also variation in the growth components among the varieties of soybean

Table 1: Mean effect of time of introduction of maize and cropping pattern on vegetative and flowering characters of soybean in soybean/maize intercrop

\begin{tabular}{|c|c|c|c|c|c|c|c|c|}
\hline \multirow{2}{*}{$\begin{array}{l}\text { Time of } \\
\text { intro }(\mathrm{T})\end{array}$} & \multicolumn{2}{|c|}{ Plant height $(\mathrm{cm})$} & \multicolumn{2}{|c|}{ Number of branches } & \multicolumn{2}{|c|}{ Leaf area $(\mathrm{cm})$} & \multicolumn{2}{|c|}{ Days to $50 \%$ flowering } \\
\hline & 2007 & 2008 & 2007 & 2008 & 2007 & 2008 & 2007 & 2008 \\
\hline T1 & 56.8 & 65.16 & 6.5 & 6.02 & 47.45 & 45 & 40.42 & 39.75 \\
\hline $\mathrm{T} 2$ & 52.47 & 65.36 & 6.2 & 5.97 & 51.73 & 53.05 & 40.04 & 39.25 \\
\hline $\mathrm{T} 3$ & 52.5 & 62.34 & 9.7 & 6.28 & 48.31 & 48.76 & 40.14 & 39.67 \\
\hline $\operatorname{LSD}_{0.5}$ & NS & NS & NS & NS & NS & NS & NS & NS \\
\hline \multicolumn{9}{|c|}{$\begin{array}{l}\text { Cropping } \\
\text { Pattern }\end{array}$} \\
\hline CP1 & 52.5 & 62.58 & 6.7 & 5.87 & 48.36 & 45.89 & 39.5 & 39.11 \\
\hline $\mathrm{CP} 2$ & 51.78 & 60.65 & 10.2 & 5.69 & 44.37 & 43.1 & 39.5 & 39.11 \\
\hline CP4 & 54.67 & 67.95 & 6.5 & 6.18 & 51.75 & 52.14 & 39.5 & 38.67 \\
\hline CP5 & 55.77 & 65.99 & 6.4 & 6.62 & 52.89 & 54.62 & 41 & 40.33 \\
\hline $\operatorname{LSD}_{0.5}$ & NS & NS & NS & NS & 4.89 & 5.55 & 0.94 & 1.12 \\
\hline
\end{tabular}

$\mathrm{NS}=$ non significant,

$\mathrm{T} 1=$ maize planted at the time with soybean, $\mathrm{T} 2=$ maize introduce two weeks after planting soybean, $\mathrm{T} 3=$ maize introduce four weeks after planting soybean, CP1= soybean variety 1 (samsoy-2) planted sole, $\mathrm{CP} 2=$ soybean variety 2 (TGX 1448-2E) planted sole,CP4= soybean variety 1 (samsoy-1) intercrop with maize, CP5 $=$ soybean variety 2 (TGX 1448-2E) intercrop with maize 
Table 2 showed results on yield and yield component of soybean. Time of introduction of maize had no significant effects on all the parameters quantified. However, there were significant effects of cropping pattern on number of pods/plant and grain yield. Both number of pods/plant and grain yield decreased in intercrop, there was significant differences between sole planted and intercropped soybean and also among the varieties.

Table 2: Mean effect of time of introduction of maize and cropping pattern on the yield and yield components of soybean in soybean/maize intercrop.

\begin{tabular}{|c|c|c|c|c|c|c|c|c|}
\hline \multirow{2}{*}{$\begin{array}{l}\text { Time of } \\
\text { introduction } \\
\text { (T) }\end{array}$} & \multicolumn{2}{|c|}{ No of pods per stand } & \multicolumn{2}{|c|}{ No of seeds per pod } & \multicolumn{2}{|l|}{100 seeds wt $(\mathrm{g})$} & \multirow{2}{*}{ 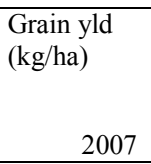 } & \multirow{2}{*}{$\begin{array}{r}\mathrm{kg} / \mathrm{ha}(\mathrm{x} 10000) \\
2008 \\
\end{array}$} \\
\hline & 2007 & 2008 & 2007 & 2008 & 2007 & 2008 & & \\
\hline $\mathrm{T} 1$ & 67.2 & 67.2 & 2.33 & 2.32 & 12.17 & 12.67 & 1.19 & 1.13 \\
\hline $\mathrm{T} 2$ & 77.2 & 77.3 & 2.24 & 2.25 & 11.79 & 12.25 & 1.27 & 1.29 \\
\hline $\mathrm{T} 3$ & 70.9 & 75.8 & 2.34 & 2.35 & 11.92 & 12.33 & 1.41 & 1.47 \\
\hline $\operatorname{LSD}_{0.5}$ & NS & NS & NS & NS & NS & NS & NS & NS \\
\hline \multicolumn{9}{|l|}{$\begin{array}{l}\text { Cropping } \\
\text { pattern }\end{array}$} \\
\hline $\mathrm{CP} 1$ & 82 & 85.2 & 2.29 & 2.24 & 12.06 & 12.67 & 1.45 & 1.51 \\
\hline $\mathrm{CP} 2$ & 67.4 & 70.4 & 2.31 & 2.31 & 11.72 & 11.78 & 1.31 & 1.26 \\
\hline $\mathrm{CP} 4$ & 65.5 & 66.2 & 2.25 & 2.31 & 12.06 & 12.56 & 1.29 & 1.57 \\
\hline $\mathrm{CP} 5$ & 68.2 & 69 & 2.35 & 2.36 & 12 & 12.67 & 1.12 & 1.04 \\
\hline $\operatorname{LSD}_{0.5}$ & 11.32 & 11.26 & NS & NS & NS & NS & 0.14 & 0.27 \\
\hline
\end{tabular}

$\mathrm{NS}=$ non significant,

$\mathrm{T} 1=$ maize planted at the time with soybean, $\mathrm{T} 2=$ maize introduce two weeks after planting soybean, $\mathrm{T} 3=$ maize introduce four weeks after planting soybean, CP1= soybean variety 1 (samsoy-2) planted sole, $\mathrm{CP} 2=$ soybean variety 2 (TGX 1448-2E) planted sole,CP4= soybean variety 1 (samsoy-1) intercrop with maize, CP5= soybean variety 2 (TGX 1448-2E) intercrop with maize

Results of mean effects of different times of introduction and cropping patterns on the vegetative and flowering data of maize are as presented in table 3 . There were significant differences in the vegetative and flowering traits of maize for the different time of introduction of maize. Results also showed significant differences between four weeks of introduction $\left(\mathrm{T}_{3}\right)$ and the other times of introduction $\left(\mathrm{T}_{1}\right.$ and $\left.\mathrm{T}_{2}\right)$ for plant height (which decreased with delayed introduction of maize). For days to $50 \%$ tasseling, simultaneous planting of maize and soybean $\left(\mathrm{T}_{1}\right)$ and introduction of maize at two weeks $\left(\mathrm{T}_{2}\right)$ were not significantly different but showed significant lower values compared with introduction of maize at four weeks $\left(\mathrm{T}_{3}\right)$. For days to $50 \%$ silking, two weeks of introduction of maize showed higher values with no significant differences among the various times of introduction. Number of leaves per plant showed the same trend as days to $50 \%$ silking. There were no significant effects of cropping pattern on $50 \%$ tasseling and silking as well as number of leaves per plant. 
Cropping pattern significantly affected plant height, there were highly significant differences between maize planted sole $\left(\mathrm{CP}_{3}\right)$ and intercropped maize $\left(\mathrm{CP}_{4}\right.$ and $\left.\mathrm{CP}_{5}\right)$ for plant height.( Maize planted sole grew taller than intercropped maize). Furthermore, there were highly interaction effects of time of introduction and cropping pattern $(\mathrm{T} \times \mathrm{CP})$ on plant height and number of leaves per plant (Table 4). Plant height both for sole and intercrop maize decreased with delayed time of introduction. However, for number of leaves per plant, maize planted sole did not significantly differed from intercropped maize

Table 3: Mean effect of time of introduction of maize and cropping pattern on some maize vegetative

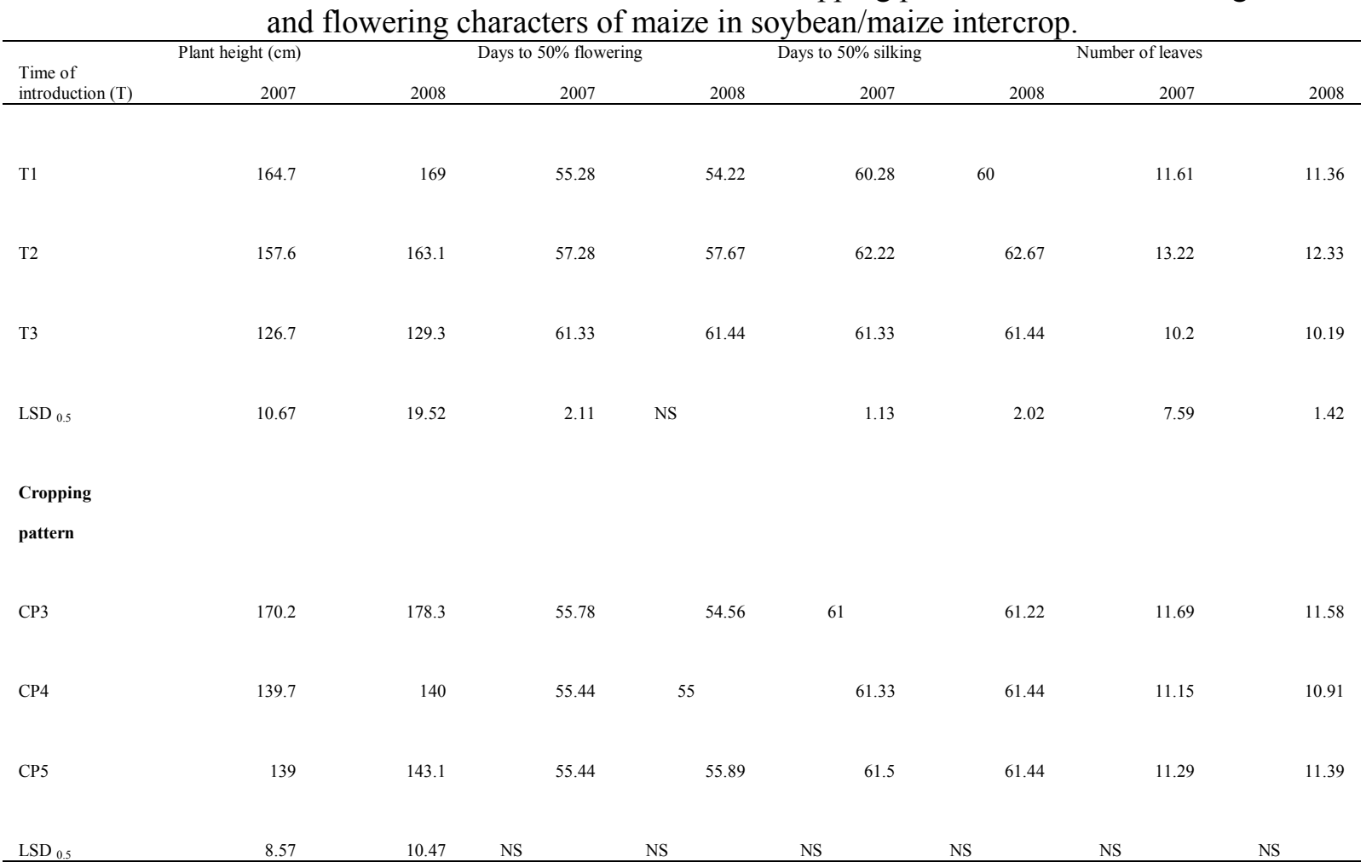

NS = non significant

$\mathrm{T}_{1}=$ maize planted at the same time with soybean, $\mathrm{T}_{2}=$ maize introduce two weeks after planting

$\mathrm{T}_{3}=$ maize introduce four weeks after planting soybean.

$\mathrm{CP}_{3}=$ maize planted sole, $\mathrm{CP}_{4}=$ maize intercropped with samsoy-2, $\mathrm{CP}_{5}=$ maize intercropped with

TGX 1448-2E

Table 4: Interaction effects of time of introduction of maize $\mathrm{x}$ cropping pattern on maize percentage survival and percentage barrenness.

\begin{tabular}{lccccc}
\hline $\begin{array}{l}\text { Time of } \\
\text { Introduction }\end{array}$ & $\begin{array}{c}\text { Cropping } \\
\text { pattern }\end{array}$ & \multicolumn{2}{c}{ \% Survival } & \multicolumn{2}{c}{ \% barrenness } \\
& & & 2008 & 2007 & 2008 \\
\hline & $\mathrm{CP}_{3}$ & 93.8 & 99 & 5.5 & 6.3 \\
$\mathrm{~T}_{1}$ & $\mathrm{CP}_{4}$ & 94.79 & 97.9 & 11.3 & 11.7 \\
& $\mathrm{CP}_{5}$ & 94.7 & 94.0 & 13.4 & 15.0 \\
& $\mathrm{CP}_{3}$ & 93.75 & 94.6 & 6.2 & 6.4 \\
$\mathrm{~T}_{2}$ & $\mathrm{CP}_{4}$ & 86.48 & 89.6 & 4.98 & 15.7 \\
& $\mathrm{CP}_{5}$ & 84.35 & 86.17 & 16.6 & 21.0 \\
& $\mathrm{CP}_{3}$ & 89.58 & 87.5 & 10.0 & 17.5 \\
$\mathrm{~T}_{3}$ & $\mathrm{CP}_{4}$ & 44.78 & 29.2 & 52.4 & 52.4 \\
& $\mathrm{CP}_{5}$ & 39.58 & 28.75 & 54.6 & 55.6 \\
$\mathrm{LSD}_{0.5}$ & & 10.5 & 11.3 & 10.46 & 13.14 \\
\hline
\end{tabular}


Results of yield and yield component of maize as influenced by time of introduction of maize and cropping pattern are as shown in table 5.There were significant differences in the ear diameter, ear length, percent barrenness, percent survival, 100 - seed weight and grain yield for the different time of introduction of maize. The result showed that these parameters (excerpt percent barrenness which increased) decreased with delayed maize introduction.

Significant differences between four weeks of maize introduction $\left(T_{3}\right)$ and other times of introduction of maize $\left(T_{1}\right.$ and $\left.T_{2}\right)$ for percent survival, percent barrenness and grain yield were also observed, while significant differences existed between the various times of introduction of maize for ear length and 100 - seed weight.

Cropping pattern significantly affected ear diameter, ear length, percent survival, percent barrenness and grain yield. Maize sole $\left(\mathrm{CP}_{3}\right)$ significantly differed from intercropped maize $\left(\mathrm{CP}_{4}\right.$ and $\left.\mathrm{CP}_{5}\right)$ for ear length, ear diameter, percent survival and grain yield (all of which were lower in intercropped maize ) but percent barrenness increased in intercropping while no significant differences were observed for 100 - seed weight. Significant interaction effects occurred between time of introduction and cropping pattern (T x CP) for percent survival and percent barrenness.

Table 5: Mean effect of time of introduction of maize and cropping pattern on the yield and yield component of maize in soybean/maize intercrop

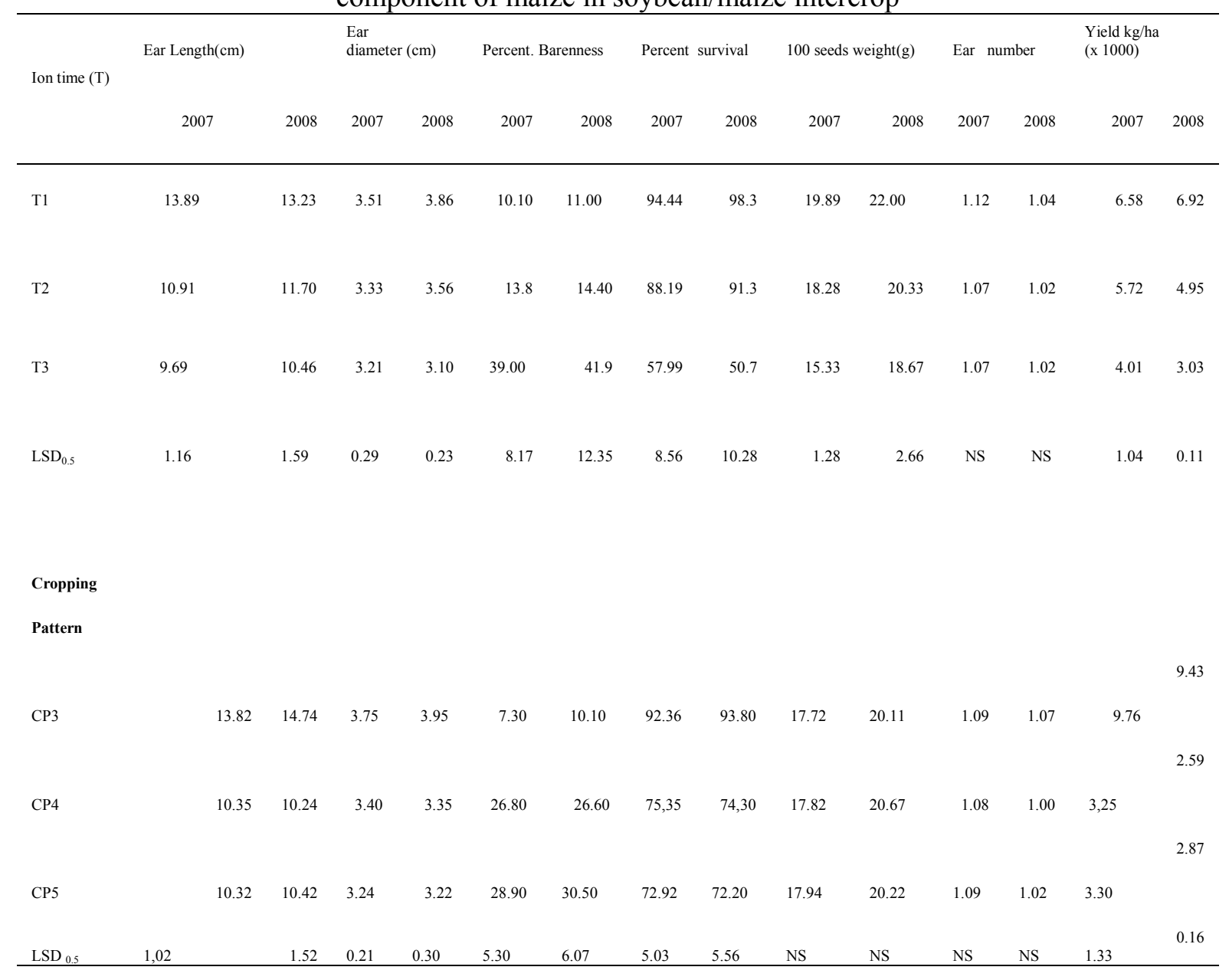

$\mathrm{T}_{1}=$ maize planted at the same time with soybean, $\mathrm{T}_{2}=$ maize introduce two weeks after planting

$\mathrm{T}_{3}=$ maize introduce four weeks after planting soybean.

$\mathrm{CP}_{3}=$ maize planted sole, $\mathrm{CP}_{4}=$ maize intercropped with samsoy- $2, \mathrm{CP}_{5}=$ maize intercropped with

TGX 1448-2E 


\section{Land Equivalent Ratios (LER) and Competitive Ratio (CR)}

The LERs and CRs of maize/soybean intercropping are as presented in Table 5. generally, LER values were greater than unity $(>1.00)$, however, introduction of maize two weeks after planting produced highest LER values (1.30 and 1.28)

Highest CR value (0.66) of maize/soybean intercropping was obtained when maize was introduced two weeks after planting soybean. Generally, CR values decreased with delayed maize introduction,

Table 5: LER and CR of soybean/maize intercrop as influenced by time of introduction of maize and variety of soybean.

\begin{tabular}{|c|c|c|c|c|c|}
\hline \multirow[t]{2}{*}{$\begin{array}{l}\text { Time of } \\
\text { introduction }\end{array}$} & \multirow[t]{2}{*}{$\begin{array}{l}\text { Variety } \\
\text { intercropped }\end{array}$} & \multicolumn{2}{|c|}{ LER (x -10) } & \multicolumn{2}{|c|}{ CR $(x-10)$} \\
\hline & & 2007 & 2008 & 2007 & 2008 \\
\hline \multirow[t]{2}{*}{$\mathrm{T} 1$} & $\begin{array}{l}\text { samsoy-2/maize } \\
\text { TGX1448- }\end{array}$ & 1.08 & 1.1 & 0.42 & 0.44 \\
\hline & $2 \mathrm{E} /$ maize & 1.06 & 1.04 & 0.66 & 0.65 \\
\hline \multirow[t]{2}{*}{$\mathrm{T} 2$} & $\begin{array}{l}\text { samsoy-2/maize } \\
\text { TGX 1448- }\end{array}$ & 1.35 & 1.36 & 0.42 & 0.47 \\
\hline & 2E/maize & 1.12 & 1.28 & 0.56 & 0.59 \\
\hline \multirow[t]{2}{*}{$\mathrm{T} 3$} & $\begin{array}{l}\text { samsoy-2/maize } \\
\text { TGX 1448- }\end{array}$ & 1.21 & 1.2 & 0.19 & 0.21 \\
\hline & 2E/maize & 1.22 & 1.22 & 0.52 & 0.54 \\
\hline
\end{tabular}

\section{Discussion}

Time of introduction of maize significantly affected maize grain yield. Maize planted simultaneously and two weeks after planting soybean out yielded that planted four weeks after planting soybean. Addo Quaye et al.,(2011) found that maize yield decrease with delay time of introduction. The reduction in grain yield of maize introduced later in maize-legume intercrop has also been demonstrated by other workers (Nnoko and Doto, 1980 ; Francis et al., 1982 ; Abdil Aziz et al., 2012). There was also reduction in maize plant height with delayed time of introduction. The reduction of the cereal component in the present study and that of the other workers has been attributed to inter-specific competition for resources. (Francis et al.,1982; Assefa and Ledin, 2001) and shading of the maize seedlings by the already established soybean plants leading to reduction in leaf area and net assimilation rate (Addo Quaye et al., 2011; Dakwa and Ocloo, 2011) In the current study, sole maize tasseled and silked at the same period with intercropped maize does not agree with the report of Ugen and Wien (1986) that sole maize tasseled and matured earlier than intercropped maize. The significant reduction in ear length and ear diameter of maize with intercropping and delayed introduction could be attributed to inter-specific competition and variation in the weather conditions especially in terms of solar radiation, humidity and temperature as the season progressed since these weather factors have a profound influence in the growth and 
development of maize. Similar findings have been reported by Elmore and Jacobs (1984) and Enyi (1973).

The much reduction in maize grain yield in intercropped could be as a result of the semi additive population used, which translates to half maize population in cereal/legume intercropping in order to reduce excessive shading (Fisher, 1977). Soybean plants grown in mixture were taller than those grown sole. These could be attributed to the shading effect of maize on soybean. Duncan et al., (1991) and Metwally et al.,( 2009) also observed taller plants in intercrop than mono-crop and attributed the increase in height to elongation of lower internodes due to shading effect of the cereal on soybean. The significant difference in soybean leaf area due to cropping pattern could be due to limited solar radiation the soybean received due to shading from the maize plant. This is consistent with the findings of Adiku et al., (1995); Polthanee et al., (2011) and Umeh and Mbah, (2010) that intercropping had little or no effect on cereal leaf area but had considerable influence on the development of intercropped legume. The lower number of soybean pods/plant obtained in intercrop could be due to shading and competitive effect by the taller maize as reported by Dalai (1977); Muoneke et al.,(2007) and Raji, (2006) Yield reduction in intercrop was related to reduce number of pods/plant because number of pods was found to be positively correlated with grain yield. (Akanda and Quayyaum, 1982; Ijoyah et al., 2013; Adeniyan and Ayoola, 2006 ;Soliman et al., 2007). There was variation in growth and yield parameters among the soybean varieties. Grain yield in the two varieties studied was significantly influenced by cropping pattern, However, soybean variety samsoy-2 out yield TGX 1448-2E variety, Umeh and Mbah, (2010) observed that there was yield differences among soybean varieties and even within and between soybean of the same maturity classes, while Polthanee et al., (20011) reported significant yield differences among cultivars of the same maturity classes and growth habit and observed that some were better adopted to shading/ intercropping environment than others this they believed was as a result of higher concentration of chlorophyll in the leaves after experienced shading/intercropping. In the current study, highest LER and CR values were obtained from two weeks delayed maize introduction perhaps because delayed maize introduction helped the soybean plant to withstand competition while at the same time not significantly affecting the maize plant.

\section{CONCLUSION}

LER characterizes the performance of an intercrop by giving the relative land area under sole crop required to produce yields achieved in intercropping. The LER values were all above unity The LER values indicated that higher yield advantages were obtained from maize introduced after two weeks of planting soybean. However, soybean variety samsoy-2 with highest number of pods per plant and seed yield was the most desirable variety for intercropping with maize, it can be concluded that in Makurdi, a location within the Guinea savanna agro-ecological zone of Nigeria, for higher yield, maize should be introduced two weeks after planting soybean using the soybean variety samsoy-2. It is however suggested that further investigation be conducted across different locations in the Guinea savanna agro ecological zone of Nigeria. 


\section{REFERENCES}

[1]Agabi, J. A; Abang, S. O and Animashaum A (1995). Nigerian environment, Macmillan, Ibadan, Nigeria. 350pp.

[2]Agboola, S. A. (1997). An agricultural atlas of Nigeria. Oxford Unversity press,(London) a. Pp 131.

[3]Abdil Aziz M. Abou-Elele; Usman, A; Abd El-Razek and Khali, H.E (2012). Yield and its components of maize/soybean intercropping systems as affected by planting time and Distribution, Australia J. of Agric and applied Sc. 6(13) :238-245.

[4]Addo-Quaye,A.A; Dankwa, A. A.and Ocloo, G. K (2011). Growth analysis of component Crops in ; A maize-soybean intercropping system as affected by time of planting and spatial arrangement, ARPN J. of Agric and Biol. Sc. 6(6): 34-44.

[5]Adeniyan, O. N and Ayoola O.T (2006). Growth and yield performance of improved soybean varieties as influenced by intercropping with maize and cassava in two contrasting Locations in south east Nigeria. Afri. J. of biotech. 5(20): 1886-1889.

[6]Akanda, M. E. and Quayyaum, M. A. (1982). Effect of intercropping soybean, mungbean, black gram and groundnut with maize. Bangladesh J. of Agric. Sc. 84:71- 78.

[7]Adiku, S. G. K.; Carbury, P. S.; Rose, C. W;Miccoumn, R. L and Brandock, R (1995) Maize (Zea mays ) cowpea (Vigna unguiculata(L) intercrop model. In Ecophysiology of tropical intercropping. Ed. Herve Sinoquet and Pabl Cruz. FNRA Editions pp 397-405.

[8]Baker, E. F. I (1978). Population, time and crop mixture. Proceedings of an International workshop on intercropping, ICRISAT. Hyederabei, 10-13 Jan. 1979, Pp 32-60

[9]Biabani, A; Hashin, M. and Herbert, S. J. (2008). Agronomic performance of two Intercropped soybean cultivars. Inter. J. plant production. 2(3): 215-221.

[10] Dalai, R. C.(1977). Effect of intercropping maize with soybean on grain yield. Trop. Agric (Trinidad) 54 (2): 189-191.

[11] Duncan, S.R; Suchapangh, W. J. (Jr) and Shroyer , J. P.(1991). Relay intercropping soybean Into wheat. In: Kansas J. prod. On agric. 3:51-55.

[12] Elmore, R. W. and Jacobs, T. A. (1984). Yield component of sorghum and soybeans of varying plant height when intercropped. Agron. J. 76:561-564.

[13] Ennin, S. A; Clegg, M. D. and francis, C. A. (2002). Resource utilization in soybean/maize Intercrop. African Crop Sc. J. 10 (3): 251-261.

[14] Enyi, B. A. C. (1973). Effect of intercropping maize or sorghum with cowpea, pigeon pea or beans. Exptal. Agric. 9:82-90

[15] Fisher, N.M. (1977). Studies in mixed cropping 11: Population pressure in maizebean Mixture. Exptal. Agric. 13:185-191

[16] M. (Fisher, N. 1980). A note on agronomic research with soybean at the institute for Agric. Res. Ahmadu Bello University, Zaria in: proceedings for annual meeting of Soybean Scientist. Nov. 3-4 1980 Zaria. Pp 34-40

[17] Francis, C. A (1978). Multiple cropping potentials of bean and maize. Hort. Sc. 113: 12-17.

[18] Francis, C. A (1986). Introduction, destribution and importance of multiple Cropping. In: Francis C. A (ed). Multiple cropping systems. Macmillan,New York, Pp 1-19. 
[19] GENSTAT, (2003). GENSTAT release 4.23, Lowes Agricultural Trust Rothamsted Experimental Station.

[20] Henriet, J. G. A; Van, E. K; Blade, S. F. and Singh, B. B. (1997). Quantitative assessment of traditional cropping systems in the Sudan Savanna of Nigeria1. Rapid survey of prevalent cropping systems. Savanna J. of Agric. Sc. 14:27-45.

[21] IITA (1986). (International Institute of Tropical Agriculture) towards sustainable Agriculture. Annual report.

[22] IITA (1989). (International Institute of Tropical Agriculture) Crop establishment manual.

[23] Ijoyah, M. O; Ogar, A. O and Ojo, A. O (2013). Soybean-maize intercropping on yield and system productivity in Makurdi, Central Nigeria. Sci. J. crop Sci. 2(4 ):82-86.

[24] Kalu, B. A. (1993). Crop recommendation for Benue state. BNARDA Ext. Bult No. 2.

[25] Langer, R. H. M and Hill, G.B (1991). Agricultural plants. Cambridge University press, U. K. 431pp.

[26] Li, L; Sun, T. H; Zhang, F. S; Li, X. L; Yang, S. C and Rengel, Z (2006). Wheat/maize or wheat/soybean intercropping. In: Yield advantages and inter specific reaction on nutrients. Field crops Res. 71: 123-237.

[27] Muoneke, C.O; Ogwuche, M. A.O and Kalu B (2007). Effect of maize planting density on the performance of maize/soybean intercropping systems in guinea savannah Agro ecosystem. Afri. J. of agric, Res. 2(12): 667-677.

[28] Mead, R. and Willey, R. W. (1980). The concept of "Land Equivalent Ratio" and Advantages in yield from intercropping. Exptal. Agric. 16:217-228.

[29] Metwally, A. A; El-Metwally, A; habbak, K.E and Abdil wahab, S. T (2009). Yield and Land equivalent ratio of intercrop soybean with maize under different intercropping pattern and high population densities. Egypt J. Agron.31(2):199-222.

[30] Mudita, I. I; Chiduza, C; Richardson-Kageler, S. J and Murungu, F. S (2008). Performance of maize (Zea mays L.) and soybean (Glycine max (L) Merill) Cultivars of varying growth habit in intercrop in sub humid environment of Zimbabwe. J. of Agron. 7(3): 229-236.

[31] NARP (1994). National Agric. Research Plan for Nigeria (Northwest Zone) Draft plan as Cited by Akin Adebayo. NOMA, $6^{\text {th }}$ May, 1996. Institute of Agric. Research, Samaru, pp 7-9.

[32] Ofori, O and Stern, W. R. (1987). Relative sowing time and density component crops in maize- cowpea intercrop systems. Exptal. Agric. 23: 41-52.

[33] Olufajo, O.O. (1986). Plant density relationship in maize/cowpea intercrop in Nigeria. Trop. Grain legume bulletin. 32:40-50.

[34] Olufajo, O.O. (1995). Sorghum/ soybean intercropping as affected by cultivar and Plant arrangement. Samaru J. of Agric. 12:3-11.

[35] Olufajo, O.O. and Singh, B.B.(2002). Advances in cowpea cropping systems research. In: C.A. Fatokun, S.A. Tarawah, B.B.Singh, P.M. Koemawa and M. Tawa (eds) challenges and opportunities for enhancing sustainable cowpea production. IITA, Ibadan. Pp 267-274. 
[36] Polthanee, A; Promsaena, K. and Laokan, A. (2011). Influence of low light intensity on Growth and yield of four soybean cultivars during wet and dry seasons of north West Thailand. Agric. Sci. 2:61-67

[37] Raji,J. A (2007). Intercropping soybean and maize in a derived savannah ecology Afri. J. of Biotech. 6(16): 1885-1887.

[38] Remison, S. U.(1982). Neighborhood effects between maize and cowpeas sown simultaneously and at intervals in rain forest zone of Nigeria. India J. of Agric Sc. 52: 500505 .

[39] Soliman, M. M; Rabie, E.M and Ragheb, S. S (2007). Response of soybean yield to late Sowing date. Arab. Unver. J. Agric. Sc. Ain. Shams univer. Cairo. 15(1): 51-59.

[40] Singh, B.B. and Ajeigbe, H.A. (2002). Improving cowpea-cereals based intercropping Systems in dry savanna of West Africa In: C.A Fatokun; Tarawah S.A; Singh, B.B; Kormawa, P.M. and Tawa, M. (eds). Challenges and opportunities for enhancing Suatainable cowpea production. Proceedings of world cowpea conference 111. IITA Ibadan. $4^{\text {th }}-8^{\text {th }} 2000$.

[41] Storck, H; Bezabih, E; berhanna, A; Andrzeja, B. and S and himelis, W.H. (1991). Farming Systems and farm management practices of small holder in Hararghe highland Ethiopia In: Farming Systems and resource economic in the tropics 11 as cited by Chemeda 1997.

[42] Sullivan, $\mathbf{P}$ (2003).Intercropping principles and production practices, Agron. Systems Guide. http.attar.ncat.org/attar.pub/PDF/intercrop.pdf

[43] Tayo, T.C. (1977). Comparative analysis of growth, development and yield of three Soybean varieties. J. of Agric. Science (Cambridge) 88:151-157.

[44] Ugen, M.A. and Wien, H.C. (1986). The effect of mature proportion and fertilizer Nitrogen on Morphology, insect pest damage, competition and yield advantage maize/bean Intercrop. Africa Crop Sc. J. 4:41-49.

[45] Umeh, S. I; Mbah, B.N. (2010). Intercrop performance of different varieties of soybean (Glycine max (L.) merill) in cassava( Manihot esculenta) based cropping system within the derived savannah zone. Afri. J. Biotech. 9(50): 8636-8642.

[46] Willey, R.W. (1997). Intercropping- its importance and research needs 1: Competition and Yield advantage. Field Crop Abstract. 32:1-10.

[47] Willey, R.W and Rao, M.R. (1980). A competitive Ratio for qualifying competition Between intercrops. Exptal. Agric. 16:117-125.

[48] Zhang, F and Li, F (2003). Using competitive and facilitations interaction in intercropping Systems enhances crop productivity and nutrient use efficiency. Plant and Soil. 248: 305-312 